\title{
THE FULL FAITH AND CREDIT CLAUSE-ITS EFFECT ON STATUTES OF LIMITATIONS
}

$T$ IS THE ESTABLISHED conflict of laws rule in America ${ }^{1}$

1 that matters of procedure are governed by the law of the forum and that substantive matters are governed by the law of the place where the cause of action arises. ${ }^{2}$ When, therefore, a court feels, in a conflicts case, that the law of the forum should apply, it is likely to characterize the problem as procedural; when it feels that the law of the locus should apply, it is apt to characterize the problem as substantive. ${ }^{3}$ In accordance with this rule, since it has long been considered well settled that statutes of limitations affect only the remedy and not the right, the law of the forum has been held to govern, although the right of action sued upon may have been created by the law of a foreign state. ${ }^{4}$ This conclusion has withstood repeated criticism, ${ }^{5}$ but analysis of some of the leading cases and certain recent developments indicate the need for a reexamination of not only the wisdom and practicality of the doctrine, but also its constitutionality.

\section{I}

There are two distinct situations in which a choice must be made between the statute of the forum and the statute of the locus: (I) where the plaintiff brings his action after the forum's statute of limitations has run, but before that of the locus has lapsed; and (2) where the action would be barred by the statute of limitations of the locus, but is not barred by that of the forum. In the first situation, the statute of the forum has almost uniformly been applied, and the argument most fre-

\footnotetext{
${ }^{1}$ For a discussion of the continental rule, see 3 RABEL, THE Conflicr of LAws: A Comparative STUdy 499 et. seq. (1950); Lorenzen, The Statute of Limitations and the Conflict of Laws, 28 YALE L.J. 492 ( $19 \times 9$ ).

${ }^{2}$ See, e.g., 3 BeAle, Conflict of Laws $\$ 5$ 84.I (1935).

${ }^{3}$ Cook, Logtcal and Legal Bases of Conflict of Laws 163 (1942).

4The Bank of the United States v. Donnally, 8 Pet. 36 I (U.S. I 834 ); Townsend v. Jemison, 9 How. 407 (U.S. r850); Walsh v. Mayer, III U.S. 31 ( 1884 ); Louisville \& Nashville R.R. v. Burkhart, I54 Ky. 92.157 S.W. IS (IgI3); In re Daniel's Estate, 208 Minn. 420, 294 N.W. 465 (1940); cf. L. D. Powell Co. v. Larkin, 52 S.D. 245, 217 N.W. 200 (1927); Restatement, Conflict OF LAWs $\$ \$ 603,604$ (I934). But cf. LeRoy v. Crowninshield, 15 Fed. Cas. 362 , No. 8,269 (C.C.D. Mass. 1820 ).

'See, e.g., Story, J. in LeRoy v. Crowninshield, ${ }_{5}$ Fed. Cas. 362, No. 8,269 (C.C.D. Mass. r 820); Hancock, Torts IN THE Conflict of Laws 133-140 (r942); Note, 79 U. OF PA. L. REv. III2 (1931). Contra: Ailes, Limitations of Actions and the Conflict of Laws, 3 I MrCH. L. Rev. 474 (I933).
} 
quently advanced to justify the outcome has been that a court should not be obliged to crowd its docket with foreign claims which, according to the lex fori, are stale. ${ }^{6}$ It has been said that, although the plaintiff has been deprived of his remedy, his right remains nevertheless, and he is free to sue upon that right in the jurisdiction where it was created. ${ }^{7}$

In the second situation, the common law rule again has been that the statute of the forum governs: the action might be brought in the forum, even though it would have been barred by the statute of limitations of the locus. ${ }^{8}$ This result, however, has largely been averted in more recent years by two factors: (a) the so-called "borrowing statutes,"

${ }^{6}$ E.g., Paine v. Drew, 44 N.H. 306 (1862); the very purpose of the statute of limitations is to provide repose for those in favor of whom it runs, Riddlesbarger v. Hartford Fire Ins. Co., 7 Wall. 386 (U.S. 1 869); House v. Carr, I 85 N.Y. 453, 78 N.E. I I I (1906); Stanley v. Stanley, 47 Ohio St. 225, 24 N.E. 493 (1890); and to this end, the statute of the forum has been held to govern, Vanderbilt v. Atlantic Coast Line R.R., I 88 N.C. 568 , 125 S.E. 387 (1924), writ of error dismissed, 270 U.S. 625 (1926); Kerper v. Wood, 48 Ohio St. 613, 29 N.E. 501 (189I). See also 3 BEale, op. cit. supra note $2, \S 603.1$; HANCOCK, op. cit. supra note 5 , at 134 ; Lorenzen, op. cit. supra note 1 , at 498 ; STORY, CONFLICT OF LAWS $\$ \S 576,577,578$ (7th ed. 1872 ).

${ }^{7}$ Willard v. Wood, I64 U.S. 502 (1896); Crampton v. D. V. Frione Co., I F. Supp. 989 (D. Conn. 1932); Attrill v. Huntington, 70 Md. 191, 16 At1. 651 ( 1889 ), rev'd on other grounds, 146 U.S. 657 (1892). STORY, op. cit. sutpra note 8, $\S 580$ : "Considered in their true light, Statutes of Limitation ... are ordinarily simple regulations of suits, and not of rights. They regulate the times in which rights may be asserted ... and do not purport to act upon those rights." This is the rule in regard to general statutes of limitations, as distinguished from those which are considered as "conditions on the right." See also ANGell, Limitations $\S \S 56-57$ (6th ed. 1876$)$.

${ }^{8}$ Campbell v. Holt, i 5 U.S. 620 ( 1885 ); Restatement, Conflict of Laws $\S 604$ (1934); cf. Theroux v. Northern Pacific R.R., 64 Fed. 84 (8th Cir. 1894) and Keep v. National Tube Co., I 54 Fed. 22 (C.C.D.N.J. 1907) (Both cases involved wrongful death actions where a limitation period in the creative statute was held to be a "condition on the right.")

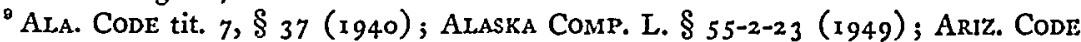
Ann. § 29-307 (1939); Cal. Code Civ. Proc. § 361 (1953); Fla. Stat. Ann. § 95:IO (1943); IdAho CODE ANN. § 5-239 (1948); IlL. Rev. STAt. c. 83, § 2 I (1951); IND. STAT. ANN. \$ 2-606 (1946); IOWA CODE ANN. § 614.7 (1950); KAN. Gen. Stat. §§ 60-310, 60-313 (1949); Kr. Rev. Stat. § 413.320 (1948); LA. Civ. Code $\S 3532$ (1945); ME. Rev. Stat. c. 99, § I1 I (I944); Mass. Gen. L. c. 260, § 9 (I933); Mich. Comp. L. § 609.9 (I948); MinN. Stat. ANn. § 541.14 (1947); Miss. Code ANN. $\$ 741$ (1942); Mo. STAT. ANN. $\$ 5 \times 6.180$ (Vernon, 1949); NEb. Rev. STAT. § 25-215 (1943); Nev. CoMp. L. § 8504 (1929); N.Y. Civ. Prac. Act $\S \S$ 13, 55 (Gilbert-Bliss, 194r); Ohio Gen. Code Ann. § y1234 (Page, 1938); 12 OKLA. Stat. ANn. \& 102 (1937); ORE. Comp. L. ANN. § 1-224 (1940); Pa. Stat. AnN. tit. 12, $\$ 39$ (Purdon, 1953); R.I. Gen. L. c. 510, $\$ 5$ (r938); TenN. COde ANN. $\$ 8607$ (1934); Tex. Rev. Civ. Stat. art. 5530 (1941); Utah Code ANN. tit. 78-12-45 (1953); VA. CODE ANN. tit. 8, § 23 (1950); WASH. Rev. Code 
and (b) the "condition on the right" rationale ${ }^{10}$ adopted by most courts. Assuming that either factor, or both, is applicable, the forum court will generally reach the same result which would have been reached if the action had been brought in the state where the right was created. ${ }^{11}$

Although the borrowing statutes differ in some respects, ${ }^{12}$ it may be said that their general purpose is to bar, in the forum, those actions which have been barred by the statute of limitations of the state where the cause of action arose. ${ }^{13}$ Perhaps the main reason for the existence of borrowing statutes is one of policy: a plaintiff against whom the statute of limitations of the locus has already run should not be allowed to follow his defendant to jurisdictions where the prescriptive period has not yet lapsed. ${ }^{14}$

In the situation where the action is brought before the statute of limitations of the forum has run, but after that of the locus has, the increasingly popular "condition on the right" rationale ${ }^{15}$ compels a court to accept the foreign limitations period if that limitation goes to the "right," rather than to the "remedy."16 It has been held that a time limitation is a "condition on the right" (I) if it is prescribed by the same statute which creates the right, ${ }^{17}$ particularly if that right was un-

tit. 4.16.290 (I952); W. VA. CODE ANN. \$ 5409 (I949); Wyo. COMP. STAT. \$ 3-520 (1945).

${ }_{10}$ See Restatement, CONFLict of Laws $\$ \$ 397,433,605$ (1934).

11 This is true at least in situations where the statute of the locus provides a shorter prescriptive period than does that of the forum. Thus, if the limitation of the locus is considered a "condition on the right" to which it refers or is made applicable by the borrowing statute of the forum, then the action is governed solely by the lex loci. However, borrowing statutes do not apply where the lex loci prescribes a longer period than does the lex fori. See Notes, 75 A.L.R. 203, 23 I (1931), 149 A.L.R. 1224, I237 (I944). Contra: John Shillito Co. v. Richardson, I02 Ky. 51, 42 S.W. 847 (1897). And the "condition on the right" rationale has been applied to the latter situation in only a few cases. See Goodrich, Conflict of Laws $\$ 86$ ( 3 d ed. 1949).

${ }^{12}$ See Notes, 75 A.L.R. 203 (I93I), 149 A.L.R. 1224 (1944).

13 BeAle, op. cit. supra note $2, \$ 604.2$. Section 604, REstatement, Conflict oF LAws, providing that the statute of limitations of the forum applies in such a case, is thus rendered inoperative. See Yntema, The Restatement of the Law of Conflict of Larws, 36 COL. L. REV. I 83,213 (1936).

16 RABEL, op. cit. supra note $\mathrm{I}$, at 508-5 II.

${ }^{15}$ Restatement, Conflict of Laws, $\$ \$ 397,435,605$ (1934).

${ }^{10}$ The Harrisburg, I I9 U.S. I 99 (I886); Maki v. George R. Cooke Co., I24 F.2d 663 (6th Cir. 1942), cert. denied, 316 U.S. 686 (1942); Wilson v. Massengill, I24 F.2d 666 (6th Cir. 1942), cert. denied, 3 I6 U.S. 686 (1942); Negaubauer v. Great Northern Ry., 92 Minn. I84, 99 N.W. 620 (I904). But cf. Davis v. Mills, I 94 U.S. $45 \mathrm{x}$ (1904); Pritchard v. Norton, 106 U.S. 124 (1882).

${ }^{17}$ Munos v. Southern Pacific R.R., 5 I Fed. I88 (5th Cir. I892); Earnest v. St. Louis, M. \& S.E. R.R., 87 Ark. 65, II 2 S.W. I4I (I908); Crosby v. Boston Elevated Ry., 238 Mass. 564, I3I N.E. 206 (I92I); Pulsifer v. Green, 96 Me. 438, 52 Atl. 
known at common law; ${ }^{18}$ and (2) if the lex loci treats it as substantive. ${ }^{10}$ As in the case of the borrowing statutes, the right is deemed to have expired when the prescriptive period set by the lex loci has run. ${ }^{20}$ Whether this rationale extends to situations where the prescriptive period of the locus is longer than that of the forum is open to question, ${ }^{21}$ but it is generally invoked only in the case where the prescriptive period of the locus is shorter. ${ }^{22}$ General statutes of limitations, as distinguished from limitations which are embodied in the statute creating the right, are not usually considered "conditions on the right," unless the statute specifically so provides. ${ }^{23}$

The characterization of statutes of limitations as procedural frequently leads to incongruous results. For example, in Merchants and Planters National Bank of Sherman v. Appleyard, ${ }^{24}$ defendant, a resident of Texas and former resident of North Carolina, executed and delivered a note to the plaintiff, also a resident of Texas. Plaintiff brought an action in North Carolina (defendant having since returned to that state) to recover on the note. The action was brought after the three-year North Carolina statute of limitations ${ }^{25}$ had run, but before the four-year Texas statute $^{26}$ had barred the action in Texas. The North Carolina Supreme Court ${ }^{27}$ rejected the defendant's contention that the North Carolina stat-

921 (1902). See Minor, Conflict of LAws $\$ 202$, at p. 495 (1901); 2 Wharton, CONFLICT OF LAWS $§ 54$ ob (3d ed. 1905).

${ }^{18}$ Colell v. Delaware, L. \& W. R.R., 80 App. Div. 342, 8o N.Y. Supp. 675 (1903); cf. Brookshire v. Burkhart, 141 Okla. I, 283 Pac. 571 (1929). But cf. Sharrow v. Inland Lines, 214 N.Y. ror, ro8 N.E. $27_{7}$ (1915).

${ }^{10}$ Restatement, Conflict of Laws $§ 605$ (r934); cf. Wood \& Selick, Inc. v. Compagnie Generale Transatlantique, 43 F.2d 94r, 943 (2d Cir. 1930); Atlantic Coast Line R.R. v. Burnette, 239 U.S. 199 (1915).

${ }^{20}$ Sea Grove Bldg. \& Loan Ass'n v. Stockton, I48 Pa. 146, 23 Atl. 1063 (1892); GoodrICH, op. cit. supra note II, $\$ 86$; STORY, op. cit. supra note $6, \S 582 \mathrm{~b}$. Semble, Perkins v. Guy, 55 Miss. 153, 30 Am. Rep. 5 10 (1877).

${ }^{21}$ See GoOdRICH, op. cit. supra note $11, \S 86$ at p. 244 n. 61 for citations.

${ }^{22}$ Platt v. Wilmot, 193 U.S. 602 (I904); Tieffenbrun v. Flannery, 198 N.C. 397, I5 S.E. 857 (I930); accord, Rosenzweig v. Heller, 302 Pa. 279, I53 Atl. 346 (r93 I) ; Restatement, Conflict of Laws $\S \S 435$, 605. Contra: Keep v. National Tube Co., 154 Fed. I2 I (C.C.D.N.J. 1907); Wilson v. Massengill, 124 F.2d 666 (6th Cir. 1942), cert. denied, 3 I6 U.S. 686 (1942); Negaubauer v. Great Northern Ry., 92 Minn. 184, 99 N.W. 620 (1904). See Notes, 79 U. OF PA. L. REv. I I12 (1931), 46 L.R.A. (N.s.) 687 (1913).

${ }^{23}$ See note 17 supra. McMerty v. Morrison, 62 Mo. 140 (1876); Hutchinson v. Ward, I92 N.Y. 375,85 N.E. 390 (1908). But of. Baker v. Stonebraker, 36 Mo. $33 \$$ (I865); Brown v. Parker, 28 Wis. 21 ( $87 \mathrm{I}$ ). See generally 3 RABEL, op. cit. supra note $I$, at pp. 504-505; Davis v. Mills, 194 U.S. 451 (1904).

${ }_{23}^{24} 8$ N.C. 145,77 S.E.2d 783 (1953). ${ }^{25}$ N.C. GEN. STAT. $\$$ 1-52 (1953).

${ }^{26}$ Tex. Crv. STAT. art. 5527 (Vernon, 1941).

${ }^{27}$ Per Denny, J. 
ute barred the action, holding that it had been tolled by operation of another North Carolina statute, which provided that the statute of limitations would not run while a defendant was absent from the state. ${ }^{28}$ Admitting that this tolling statute was enacted primarily for the benefit of plaintiffs who were citizens and residents of North Carolina, the court nevertheless extended its protection to nonresident plaintiffs. ${ }^{29}$ Thus, the fact alone that the defendant had once been a resident of North Carolina was held to support the invocation of that state's tolling statute in favor of a nonresident plaintiff, even though the cause of action arose in another jurisdiction. ${ }^{30}$

It seems certain from the majority opinion in the Appleyard case that the court's willingness to entertain the suit was prompted by the fact that the law of the locus, Texas, had not yet barred the action. ${ }^{31} \mathrm{Be}-$ cause of the strictures of the procedural-substantive rule, the court could not unequivocally apply the statute of limitations of the locus; rather, it was compelled to adopt a quite unconvincing subterfuge. ${ }^{32}$ That this opinion may lead to some embarrassment in the future is readily demonstrated by a hypothetical situation. Imagine a case in which the facts are identical with those of the Appleyard case, except that the Texas statute of limitations has also run by the time plaintiff brings his suit in North Carolina. Since the cause of action is barred by the lex loci, and since North Carolina's own prescriptive period has expired, it seems doubtful that the North Carolina court would feel as willing to entertain the suit as it was in the Appleyard case. Yet, since the

${ }^{28}$ N.C. GEN. STAT. § I-2I (I953): "If, when the cause of action accrues or judgment is rendered or docketed against a person, he is out of the State, action may be commenced, or judgment enforced, within the time herein limited after the return of the person into this State . . the time of his absence shall not be a part of the time limited for the commencement of the action, or the enforcement of the judgment."

${ }_{20} 28$ N.C. $145,148,77$ S.E.2d 783,786 (1953).

${ }^{30}$ But see 238 N.C. 145, 148, 77 S.E.2d 783, 786 (1953): "Statutes like ours [note 28 supra] and those substantially and essentially in accord therewith, have been held to toll the statute [of limitations] in such cases where neither the plaintiff nor the defendant was a resident of the forum at the tiine of the institution of the action and never was ..." (Emphasis added.)

${ }^{31}$ Although the opinion does not rest upon this ground, the court, after admitting that the tolling statute was enacted primarily for the benefit of citizens and residents, says, by way of dicta, ". . . this does not mean that our court should not be open to a nonresident plaintiff to enforce a claim on a cause of action that is not barred in the jurisdiction where such cause of action arose, where the debtor has not been a resident of this State for the statutory time necessary to bar the action" (Emphasis added.) 238 N.C. $145,148,77$ S.E.2d 783,786 (1953).

${ }^{32}$ Since the court felt bound by the rule that the limitation of the action was governed by the lex fori, it was forced to distort the tolling statute in order to reach the desired result. A characterization of the Texas statute of limitations as substantive would have avoided this trip around Robinhood's barn. 
rule has been established that the North Carolina statute of limitations is tolled in such a case, the plaintiff would still have a remedy in North Carolina. ${ }^{33}$ Indeed, if the North Carolina court is faithful to the doctrine of stare decisis, it would have to entertain such an action even if the claim arose twenty or twenty-five years before the suit is brought. ${ }^{34}$

This ludicrous result would follow only from characterization of statutes of limitations as procedural, and hence governed by the lex fori. If, on the other hand, statutes of limitations were characterized as substantive, the limitation period of the locus would automatically be adopted, and any actions arising under its laws would be barred after that period had expired, regardless of where the action might be brought. Mr. Justice Barnhill, perhaps foreseeing the potential danger of the majority's rationale in Appleyard, concurred ${ }^{35}$ in the result on the ground that the court should entertain any claim not barred by the statute of limitations of the state in which it arose. ${ }^{36}$ He expressly denied, however, that the tolling statute applied to actions on foreign claims arising out of transactions between nonresidents. ${ }^{37}$

The present rules, based though they are upon a long line of respectable precedent, ${ }^{38}$ have nevertheless been the subject of severe crit-

${ }^{33}$ Since North Carolina has no borrowing statute, the court would be compelled to follow its own rationale in the Appleyard case and thus allow the action despite the fact that the cause of action would no longer exist under the lex loci.

${ }^{34}$ But query whether the court would follow Appleyard to such an extreme in view of the emphasis it seems to place on the fact that the action was not barred by the lex loci. See note 3 I supra.

${ }^{35}{ }_{23} 8$ N.C. ${ }_{445}, 152,77$ S.E.2d 783,789 (1953) (concurring opinion).

${ }^{36}$ "Our statute, when correctly construed, is not controlling. Instead, wc must look to the prescriptive statute of the State in which the parties resided at the time the contract was made and the cause of action accrued to determine whether plaintiff's clain is barred. That was the statute in the contemplation of the parties when the contract was made." Id. at $\times 55,77$ S.E.2d at 792 . Justice Barnhill also disagreed with the majority as to the interpretation of the word "return" in the tolling statute (note 28 supra). The majority construed the statute as operating against a defendant who had never been a resident of North Carolina, while Mr. Justice Barnhill felt that the word "return" implied that the statute applied only to a defendant who had been a resident and had left.

${ }^{37}$ Mr. Justice Barnhill based his concurrence mainly on the rationale that the note sued upon was "property" governed by the law of Texas,' and that since that law would allow the action North Carolina should also allow it. 238 N.C. 145, 153, 77 S.E.2d 783,790 ( 1953 ). "Property" is used in its generic sense-including not only the note itself, but also the cause of action. See Williams v. Atlantic Coast Line R.R., ${ }_{53}$ N.C. 360,69 S.E. 402 ( $19 \times 0$ ). Mr. Justice Barnhill's approach suggests a leaning toward the characterization of statutes of limitations as substantive, but he too seems reluctant to defy the weighty authority to the contrary.

${ }^{38}$ See, e.g., STORY, CONFLICT of LAWs $\$ \$ 578$ et seq. (7th ed. 1872 ). 
icism in recent years. ${ }^{39}$ A right without a remedy, it has been said, is a "meaningless scholasticism." The enactment of borrowing statutes by thirty-three states ${ }^{41}$ and the fast-growing acceptance of the "condition on the right" rationale is symptomatic of an increasing recognition that time limitation on a cause of action is, in reality, a substantive matter to be governed by the law of the state which has created the right. ${ }^{42}$ Further, for the purposes of the Erie v. Tompkins doctrine, ${ }^{43}$ federal courts characterize state ${ }^{44}$ statutes of limitations as substantive and apply the same prescriptive period as would be applied by the respective state courts ${ }^{45}$-patent recognition of the fact that substantive right may well depend on the limitation period adopted. ${ }^{46}$

Conforming with the spirit of the reforms reflected in the borrowing statutes and the "condition on the right" rationale, where a plaintiff brings his action after the statute of the forum has run, but before that

\footnotetext{
${ }^{30}$ E.g., 3 RABEL, op. cit. supra note $x$, at 521 ; HANcock, op. cit. supra note 5, at I40.

${ }^{10}$ See Learned Hand, J. in Wood \& Selick, Inc. v. Compagnie Generale Transatlantique, 43 F.2d 94r, 943 (2d Cir. 1930), where it was held that a French statute of limitations on a contract action is a mere bar to a remedy and not a substantive
} matter or a "condition on the right."

${ }^{1}$ See note 9 supra.

${ }^{2}$ Cf. RABEL, op. cit. supra note $\mathrm{x}$, at 504 et seq.

${ }^{13}{ }_{3} 4$ U.S. 64 ( 1938 ). It was held in this case that the federal courts must adopt the substantive law of the place where the cause of action arose. In Klaxon Co. v. Stentor Co., $3 x_{3}$ U.S. 487 (194I), the United States Supreme Court extended this rationale to state conflict of laws rules. Thus, it has been held that the conflict of laws rules of a federal court sitting in Delaware ". . . must conform to those prevailing in Delaware's state courts. ... Delaware is free to determine whether a given matter is to be governed by the law of the forum or some other law. ..." 3 I $_{3}$ U.S. 487 , 496, 497. But see Jackson, J., dissenting in Wells v. Simonds Abrasive Co., 345 U.S. 514,519 (1953).

"As to characterization of federal statutes of limitations, see Note, 49 YALE I. J. 738 (1940). See also Campbell v. Haverhill, 155 U.S. 610 (1895) (a federal court must apply the statute of limitations of the state in which it sits, in the absence of an applicable federal statute, even though the cause of action arose under the federal law).

"In a suit brought on the equity side of a federal district court, that court is required to apply the state statute of limitations that would govern like suits in the courts of the state where the federal court is sitting. Guaranty Trust Co, v, York, 326 U.S. 99 (1945); cf. Ragan v. Merchants Transfer Co., 337 U.S. 530 (1949) (federal court bound by tolling provision of the state in which it sits).

"See, e.g., Guaranty Trust Co. v. York, 326 U.S. 99, rog (1945) : "The question is whether such a statute [of limitations] concerns merely the manner and the means by which a right to recover, as recognized by the State, is enforced, . . . or whether such statutory limitation is a matter of substance... does it significantly affect the result of a litigation for a federal court to disregard a law of a State that would be controlling in an action upon the same claim by the same parties in a State court?" 
of the locus bars the action, the forum should surely allow the action. ${ }^{47}$ Otherwise, the plaintiff would be deprived at least of a piece of his right. ${ }^{48}$ Nor should a court be heard to say that it will apply its own statute of limitations because it wishes to avoid litigation of "stale" claims, or because it does not want to crowd its dockets with foreign actions. ${ }^{49}$ Since the occurrence or transaction from which the cause of action arises is governed by the law of a foreign jurisdiction to which the parties have subjected themselves, neither can complain if the life span of the cause of action is governed by that law.50 Further, the rationalization that the plaintiff is free to sue upon his right in the state where it was created ${ }^{51}$ overlooks the fact that the courts there may not have jurisdiction over the defendant. ${ }^{52}$

Where the plaintiff brings his action before the statute of limitations of the forum has run, but after that of the locus has, the courts should also apply the statute of the locus. ${ }^{53}$ It is true that the borrowing statutes and the "condition on the right" rationale virtually effect this desired result in a large percentage of cases; ${ }^{54}$ but in jurisdictions where these factors are not operative, the courts may still apply the statute

${ }^{47}$ But the view expressed in Restatement, Conflict of LAWs $\S 603$ (1934) still prevails: "If action is barred by the statute of limitations of the forum, no action can be maintained though action is not barred in the state where the cause of action arose." See also 3 BEALE, op. cit. supra note 2, §603.1.

${ }^{4}$ Although the plaintiff is possessed of the remaining piece of the right by the law of the place which created it, nevertheless it is only a worthless abstraction if jurisdiction over the defendant cannot there be secured. But cf. LeRoy v. Crowninshield, 15 Fed. Cas. 362 , No. 8,269 (C.C.D. Mass. 1820 ).

${ }^{10}$ Furthermore, the very raison d'etre of our courts is that justice is done, and a crowded docket is a poor excuse for abdication of that responsibility. But Story's view still clings to American law: "Every nation must have a right to settle for itself the times and modes and circumstances within and under which suits shall be litigated in its own courts. There can be no pretense to say that foreigners are entitled to crowd the tribunals of any nation with suits of their own which are stale and antiquated to the exclusion of the common administration of justice between its own subjects." STORY, op. cit. supra note 6 , at 720 .

${ }^{50}$ The place of contracting is determined by the lex fori. Illinois Fuel Co. v. Mobile \& Ohio R.R., 319 Mo. 899, 8 S.W.2d 834 (1928), cert. denied, 278 U.S. 640 (1928). See 3 BEALE, op. cit. supra note $2, \S 3 \mathrm{II} .2$; GoODRICH, op. cit. supra note $1 x, \S \S 106,107$. For a discussion of the governing law in torts, see, e.g., HANcock, op. cit. supra note 5 , at 2 I et seq.

"5i See note 7 supra.

${ }^{52}$ See note 48 supra.

${ }^{5} 3$ But see Restatement, Conflict of LAws $\$ 604$ (1934): "If action is not barred by the statute of limitations of the forum, an action can be maintained, though action is barred in the state where the cause of action arose." Compare § 397.

${ }^{54}$ See RABEL, op. cit. supra note I, at 504 et seq. 
of the forum and thus re-create a right which in reality was rendered non-existent by the limitation period of the locus. ${ }^{55}$

\section{II}

Independent of substantive policy considerations involved, there is the further question as to whether the full faith and credit clause of the Constitution $^{\tilde{5} 6}$ requires that the forum adopt the limitations imposed upon a right of action by the state in which it was created. The question was answered in the negative in the leading case of McElmoyle v. Cohen. ${ }^{57}$ There an action was brought in Georgia to enforce a South Carolina judgment after Georgia's statute of limitations on the action had run. The United States Supreme Court, regarding the defense of limitations as being only a "plea to the remedy," concluded that the full faith and credit clause did not apply to procedural matters. Furthermore, said the Court, a state is not required by the full faith and credit clause to apply in its own courts foreign law ${ }^{59}$ which is against the policy of the forum. ${ }^{60}$ Thus, it has subsequently been held that a foreign statute of limitations which keeps alive an action which is barred by the statute of the forum need not be adopted, as it conflicts with the latter's policy against stale claims. ${ }^{61}$

The McElmoyle rule seems never to have been questioned until 1947, when Order of United Commercial Travelers v. Wolfe $e^{62}$ was decided. In that case the plaintiff was seeking in South Dakota bene-

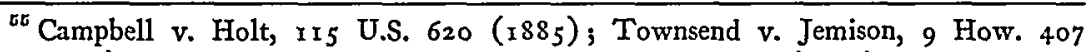
(U.S. I850); Pearsall v. Dwight, 2 Mass. 84, 3 Am. Dec. 35 (I806).

${ }^{60}$ U.S. Const. ART. IV, $\$ \mathrm{I}$ : "Full Faith and Credit shall be given in each State to the public Acts, Records, and judicial proceedings of every other State. And Congress may by general laws prescribe the Manner in which such Acts, Records and Proceedings shall be proved and the Effect thereof."

${ }^{57}$ I $_{3}$ Pet. 3 I2 (U.S. I 839 ).

${ }^{48} I d$, at 327 .

"0 "Foreign law" is used here to denote a foreign judgment as distinguished from rights created by foreign statute. See ACT OF 26 MAY, 1790, I STAT. 122 (1856): ". . . And the said records and judicial proceedings... shall have such faith and credit given to them in every court within the United States as they have by law or usage in the courts of the state from whence the said records are or shall be taken."

${ }^{00}$ "Prescription is a thing of policy, growing out of the experience of its necessity ... the effect intended to be given under our Constitution to judgments is that they are conclusive only as regards the merits. ..." I3 Pet. 3 I2, 327, 328 (U.S. I839).

${ }^{01}$ Randolph v. King, 20 Fed. Cas. 260 , No. II,560 (C.C.D. Ohio, ${ }_{1867}$ ); cf. Alabama State Bank v. Dalton, 9 How. 522 (U.S. I 850 ); Scheminel v. Cooksley, 256 II1. 4I2, I00 N.E. I4I (I9I2) (application of forun's statute of limitations to action on a foreign judgment not a denial of full faith and credit); Great Western Tel. Co. v. Purdy, I62 U.S. 329 ( 1896$)$. But cf. Keyser v. Lowell, II 7 Fed. 400 (8th Cir. I902) (reasonable time must be allowed for enforcing a foreign judgment).

${ }^{02} 33$ I U.S. 586 ( 1947 ). 
fits claimed to have arisen under a contract which plaintiff's decedent had entered into with the defendant fraternal society, an Ohio corporation. Pursuant to a provision in the defendant's constitution, the contract contained a six-month limitation on actions brought upon it. ${ }^{03}$ Such a provision was permissible ${ }^{6 t}$ under Ohio statutes, ${ }^{65}$ but was expressly disallowed by a South Dakota statute, ${ }^{60}$ that state having a statute which imposed a general limitation of six years on all contract actions. ${ }^{07}$ The South Dakota courts allowed recovery, taking no cognizance of defendant's plea of the six-month limitation. ${ }^{68}$ The United States Supreme Court reversed on appeal. Mr. Justice Burton, speaking for the majority, recognized the common law rule that each state is free to apply its own limitation period, but concluded that the full faith and credit clause safeguards ". . . in each state, the effectiveness of the public acts of every other state as expressed in the rights and obligations of members of fraternal societies." ${ }^{30}$ Mr. Justice Black dissented, ${ }^{70}$ however, pointing out that, under the McElmoyle rule, whichever limitation policy a forum chooses to follow-to borrow or refuse to borrow the prescriptive period of the creating state-“... it is free, so far as the full faith and credit clause is concerned, to do so. ... The plain effect of today's decision is to overrule the McEymoyle case."ri Indeed, the $W$ olfe case does seem to change the rule regarding the applicability of the full faith and credit clause to statutes of limitations. ${ }^{72}$ The fact

${ }^{63}$ Const., Order of United Commercial Travelers of America, Art. IV, §xx.

${ }^{64}$ It was, however, not made mandatory.

${ }^{65}$ Ohio. Gen. Code $\$ \S 9462$ et seq. (Page, 1938); see Appel v. Cooper Ins. Co., 76 Ohio St. 52, 8o N.E. 955 (1907); Bartley v. National Business Men's Ass'n, 109 Ohio St. $585,14.3$ N.E. ${ }_{386}$ (1924) (reasonable limitation period in contract enforceable); see also Modern Woodmen v. Myers, 99 Ohio St. 87, 124 N.E. 48 (1918) (fraternal benefit contract controlled by law of incorporating state).

${ }^{68}$ S.D. REV. CODE $\$ 897$ (1919): "Every stipulation or condition in a contract, by which any party thereto is restricted from enforcing his rights under the contract by the usual legal proceedings in the ordinary tribunals, or which limits the time within which he may thus enforce his rights, is void."

${ }^{67}$ S.D. REv. CODE $§ 2298$ (1919).

${ }^{68}$ Wolfe v. Order of United Commercial Travelers of America, 70 S.D. 452, 18 N.W.2d 755 (1945).

${ }^{68}$ Order of United Commercial Travels v. Wolfe, 33I U.S. 586, 609 (1947). A stipulation in a foreign contract fixing the period of limitations in generally enforceable. Brooks v. Travelers Protective Ass'n of America, 47 F.2d 618 (E.D.N.Y. 1931); cf. Royal Arcanum v. Green, 237 U.S. 53 I (1915); Sovereign Camp v. Bolin, 305 U.S. $66(1938)$.

${ }_{70} 33$ I U.S. 586, 625 (1947). Douglas, Murphy and Rutledge, JJ., joined.

${ }^{71}$ Id. at 627 .

${ }^{72}$ The full faith and credit clause has not been fully exploited, and it is believed that little effort would be required to extend its mandates to prescriptive statutes. Sec Jackson, Full Faith and Credit-The Lawyer's Clause of the Constitution, 45 CoL. L. 
that the clause was applied to enforce a statute which only permitted, and did not require, limitation periods to be written into certain insurance contracts would seem, a fortiori, to reflect a tendency to regard prescriptive statutes as substantive enough to be entitled to full faith and credit. $^{73}$ Nevertheless, it is doubtful that the Wolfe case can be construed as having completely upset the $M c E l m o y l e$ rule, since the courts subsequently tended still to follow that rule and to distinguish the Wolfe case. ${ }^{74}$

The landmark case of Hughes v. Fetter ${ }^{75}$ was decided in I95I. There, the plaintiff sued in a Wisconsin court upon an action based on an Illinois wrongful death statute. ${ }^{76}$ Wisconsin's wrongful death statute created a right of action only for deaths occurring in that state. ${ }^{77}$ The Wisconsin Supreme Court affirmed ${ }^{78}$ the decision of the trial court that the Wisconsin statute established a local policy against Wisconsin's entertaining suits brought under wrongful death acts of other states. ${ }^{79}$ On appeal, the United States Supreme Court reversed, holding that the local policy of Wisconsin must yield to the policy of the full faith and credit clause, since Wisconsin ". . . has no real feeling of antagonism against wrongful death suits in general." ${ }^{380}$ The effect of this decision

Rev. I (1945); Note, 15 U. of ChI. L. REv. 409 (1948); cf. Notes, 43 IlL. L. REv. II6 (I948), 57 YALE L. J. I39 (I947).

${ }^{73}$ But in Northwestern Brewers Supply Co. v. Vorhees, 356 Mo. 699, 203 S.W.2d 422 (1947), it was held that full faith and credit does not necessarily mean full faith and credit for the full term of the duration of the judgment under the law of the place where the judgment was obtained. Accord, Ohio v. Porter, I2 I P.2d 538 (Cal. App. I942).

${ }^{73}$ See Florida Wholesale Drug Inc. v. Ronson Art Metal Works, Inc., r ro F. Supp. 573, 575 (D.N.J. 1953); cf. Lewis v. Reconstruction Finance Corp., 177 F.2d 654 (D.C. Cir. 1949).

${ }^{75} 34$ I U.S. 609 (195 I).

${ }^{70}$ ILL. ANn. STAT. c. 70, §§ 1, 2 (Smith-Hurd, 1936), IlL. REv. StAT. c. 70, $\$ \S \mathrm{I}, 2$ ( $195 \mathrm{I})$.

${ }^{77}$ WIS. STAT. $\$ 331.03$ ( 1947 ) : "Whenever the death of a person shall be caused by a wrongful act, neglect or default, and the act, neglect or default is such as would, if death had not ensued, have entitled the party injured to maintain an action and recover damages in respect thereof, then and in every such case the person who, or the corporation which, would have been liable, if death had not ensued, shall be liable to an action for damages notwithstanding the death of the person injured; provided, that such action shall be brought for a death caused in this state."

${ }^{78}$ Hughes v. Fetter, 257 Wis. 35,42 N.W.2d 452 (1950).

${ }^{70}$ Said the Wisconsin Supreme Court, per Fairchild, J.: "It has been repeatedly declared to be the law that it was not intended by [the full faith and credit clause] to give to the laws of one state any operation in other states, except by permission . . . by those states. . . . The policy of Wisconsin against the maintenance of such an action having been created positively in a statute, that policy must prevail." Id. at 37 , 38,42 N.W.2d at 453 .

${ }_{80} 34 \mathrm{I}$ U.S. 609,612 (1951). Mr. Justice Black spoke of the policy of the full faith and credit clause as being the "strong unifying principle ... looking toward maxi- 
was to force the forum, by means of the full faith and credit clause, to recognize a foreign statutory right, even though that particular right had expressly been denied existence by the legislature of the forum. ${ }^{\mathbf{8 1}}$

In Wells v. Simonds Abrasive Co., ${ }^{82}$ however, the United States Supreme Court has refused to extend the Hughes rationale to its logical conclusion in the situation where a court must choose between two conflicting statutes of limitations. In that case, the plaintiff's intestate was killed in Alabama as a result of injuries caused by the bursting of a grinding wheel manufactured by the defendant, a Pennsylvania corporation. Suit was brought in a Pennsylvania federal district court ${ }^{83}$ to enforce a right created by an Alabama statute. ${ }^{84}$ The United States Supreme Court affirmed the lower court's decision denying recovery on the ground that the action was barred by Pennsylvania's one-year statute of limitations on wrongful death actions, ${ }^{85}$ despite the fact that suit was brought within the two-year period of limitations provided by the Alabama statute creating the right. Hughes $v$. Fetter was held not to compel a state to adopt a foreign limitation period, ${ }^{80}$ although Mr.

mum enforcement in each state of the obligations or rights created or recognized by the statutes of sister states. . .." In Magnolia Petroleum Co. v. Hunt, 320 U.S. 430 (1943), rehearing denied, 321 U.S. Sor (1944), it was held that the Louisiana court was bound by the full faith and credit clause to recognize a Texas award as res judicata on a workmen's compensation claim. But cf. Alaska Packers Ass'n v. Commission, 294 U.S. 532 (1935).

${ }^{81}$ Thus Frankfurter, J., with whom Reed, Jackson and Minton, JJ, joined, said in dissent: "Few interests are of more dominant local concern than matters governing the administration of law. This vital interest of the States should not be sacrificed in the interest of a merely literal reading of the Full Faith and Credit Clause." 341 U.S. $609,620(195 \mathrm{I})$.

${ }^{82} 345$ U.S. 514 (1953).

${ }^{83}$ Wells v. Simonds Abrasive Co., ro2 F. Supp. 519 (E.D. Pa. 1951), aff'd, 195 F.2d 814 (3d Cir. 1952).

${ }^{84}$ Ala. Code tit. 7, $\$ \times 23$ (1940). In Parker v. Fies \& Sons, 243 Ala. 348, 350, ro So.2d 13, I5 (1942), the Alabama Supreme Court construed the two-year limitation embodied in the statute as being "of the essence of the cause of action." But under the decision in Rosenzweig v. Heller, 302 Pa. 279, I53 Atl. 346 (1931), the Pennsylvania courts would not be bound to recognize it as such.

${ }^{85}$ PA. STAT. tit. 12, § 1603 (Purdon, 1931).

${ }^{80}$ The crucial factor in Hughes $v$. Fetter was said to be that "the forum laid an uneven hand on causes of action arising within and without the forum state. . . . Here Pennsylvania applies her one-year limitation to all wrongful death actions wherever they may arise." 345 U.S. 514, 518, 519 (1953). In First National Bank of Chicago v. United Air Lines, 342 U.S. 396,398 (1952), it was held that a statute [ILL. REv. STAT. c. 70, $\S_{2}$ (195I)] which forbade the entertainment of a wrongful denth action in Illinois "where a right of action for such death exists under the laws of the place where such death occurred and service of process in such suit may be had upon the defendant is such place" violated the full faith and credit clause. "That Illinois is 
Justice Jackson Jackson, dissenting, ${ }^{87}$ argued that the doctrine of Erie v. Tompkins ${ }^{88}$ requires the forum to apply the statute of limitations of the state whose substantive law governs the case-in this instance Alabama's. ${ }^{89}$ The full faith and credit clause, said he, requires that the law of the place where the cause of action arose "will follow the cause of action in whatever forum it is pursued."

It is suggested that the Court in the $W$ ells case, by refusing to label prescriptive statutes as substantive, and by refusing to apply the full faith and credit clause thereto, missed an opportunity to resolve all conflict concerning the proper choice of law. ${ }^{91}$ An opposite holding would have unequivocally required state and federal courts to apply the prescriptive period specified by the law of the state creating the right to measure the duration of that particular right. ${ }^{22}$ And as long as the full faith and credit clause, under the interpretation adopted in Hughes v. Fetter, may operate to force upon the forum a statutory policy at least partially in conflict with its own, there would appear to be no sound reason for the Court's refusal to sanction the statutory limitation of that policy. ${ }^{93}$

The applicability of the full faith and credit clause should not be made to turn on a balance of convenience between litigants, but rather

willing for its courts to try some out-of-state death actions is no reason for its refusal to grant full faith and credit as to others."

345 U.S. $5 x_{4}, 5 \times 9$ (1953). Black and Minton, JJ., joined.

${ }_{38}^{804}$ U.S. 64 (1938). See note 43 supra.

${ }^{80}$ But cf. Sampson v. Channel, 110 F.2d 754 (1st Cir. 1940), cert. denied, 310 U.S. 650 (1940) (federal court sitting in Massachusetts bound to apply Massachusetts rule regarding burden of proof on question of contributory negligence). See also Klaxon Co. v. Stentor Co., 3 I 3 U.S. 487 (1941), note 43 supra.

${ }^{00} 345$ U.S. 514, 52 I (1953).

${ }^{01}$ Even the dissent did not adopt the desired approach, but came nearest by stating that "it is Alabama law that giveth and only Alabama law that taketh away." (id. at 527). But this does not effect the case where the prescriptive period of the locus is shorter than that of the forum.

${ }^{02}$ Moreover, it would eliminate the anomaly of the federal courts characterizing state statutes of limitations as substantive for the purposes of the Erie doctrine while the states are characterizing the same statutes as procedural.

${ }^{03}$ See, e.g., Cardozo, J., in Loucks v. Standard Oil Co. of New York, 224 N.Y. 99, Ixo, XII, 120 N.E. I98, 201 (1918), where the question was whether the New York courts were bound to apply a Massachusetts law regarding the distribution of damages in wrongful death actions: "Our own scheme of legislation may be different. We may even have no legislation on the subject. That is not enough to show that public policy forbids us to enforce the foreign right. A right of action is property. ... We are not so provincial as to say that every solution of a problem is wrong because we deal with it otherwise at home." But see McMillen v. Douglas Aircraft Co., 9o F. Supp. 670, 673 (S.D. Cal. 1950) (California limitation governs-no violation of the full faith and credit clause). 
should depend upon which law ought to govern. Thus, the important point is not whether a particular statute applies only to procedural matter and does not carry its weight into foreign jurisdictions, but whether the refusal to recognize that statute will result in an outcome that could not possibly have occurred had the action been brought where it was created. Full faith and credit is not given to a right created by a foreign statute when the forum enforces it for a period either longer or shorter than that intended by the state which created it.

John A. Carnahan 